\title{
Vertical hydrological exchange, and ecosystem properties and processes at two spatial scales along a floodplain river (Tagliamento, Italy)
}

\author{
M. Doering ${ }^{1,4}$, U. Uehlinger ${ }^{1,5}$, AND K. Tockner ${ }^{1,2,3,6}$ \\ ${ }^{1}$ EAWAG, Swiss Federal Institute of Aquatic Science and Technology, 8600 Dübendorf, Switzerland \\ ${ }^{2}$ ETH, Institute of Integrative Biology, Swiss Federal Institute of Technology, Zurich, Switzerland \\ ${ }^{3}$ IGB, Leibniz-Institute of Freshwater Ecology and Inland Fisheries, Berlin, and Institute of Biology, \\ Freie Universität Berlin, Germany
}

\begin{abstract}
We examined the effect of vertical hydrological exchange on physicochemical variables, periphyton biomass (ecosystem properties), and sediment respiration (ecosystem process) at 2 spatial scales along a large gravel-bed river (Tagliamento River, northeastern Italy). At the regional scale, we investigated a 29-km-long, expanding and contracting, losing (average flow decrease $2.5 \mathrm{~m}^{3} \mathrm{~s}^{-1} \mathrm{~km}^{-1}$ ) and a 12.5-km-long, stable, gaining (average increase $0.3 \mathrm{~m}^{3} \mathrm{~s}^{-1} \mathrm{~km}^{-1}$ ) reach. At the local scale, we sampled riffle head and riffle tail units nested within the losing and gaining reaches. At the regional scale, we characterized vertical exchange by strong downwelling (negative vertical hydraulic gradient; VHG) in the losing and moderate upwelling (positive VHG) in the gaining reach. Nutrients, such as $\mathrm{NO}_{3}-\mathrm{N}$ and dissolved $\mathrm{N}(\mathrm{DN})$, and periphyton biomass (AFDM) showed a significantly $(p<0.05)$ lower concentration in the losing than in the gaining reach. A contrasting pattern emerged for sediment respiration. Expansion and contraction dynamics (i.e., drying and rewetting) in the losing reach negatively affected chlorophyll $a$ and AFDM. At the local scale, VHG was negative at riffle heads and positive at riffle tails nested in the gaining reach, but variables did not respond to vertical exchange at riffle heads and riffle tails in the losing or gaining reach. However, averaged data from riffle heads and riffle tails in the losing reach compared to averaged data for riffle heads and riffle tails in the gaining reach showed the same pattern as found in the regional investigation. Vertical exchange was apparently a major factor influencing ecosystem properties and ecosystem processes hierarchically across different spatial scales.
\end{abstract}

Key words: flood plain, spatial scales, vertical exchange, sediment respiration, periphyton, ecosystem hierarchy.

Floodplain ecosystems can be viewed as a series of spatially and hierarchically organized geomorphic entities constrained within a nested spatial context (Frissell et al. 1986, Lowe et al. 2006, Thorp et al. 2006, Parsons and Thoms 2007). Riffles and pools are nested within river reaches that are nested within stream networks, and stream networks are nested within catchments. In this composite view, bidirectional hydrological exchange between the channel and alluvial aquifer, commonly described as upwelling and downwelling, connects different geomorphic entities. The direction and strength of vertical exchange varies with hydraulic conductivity and the

\footnotetext{
${ }^{4}$ E-mail addresses: michael.doering@eawag.ch

5 urs@uehlinger.info

${ }^{6}$ tockner@igb-berlin.de
}

vertical extent of the alluvial sediments (Malard et al. 2002, Acuña and Tockner 2009), and is scale dependent (Fernald et al. 2001, Kasahara and Wondzell 2003, Poole et al. 2004, 2006). Scales of exchange range from entire river reaches where subsurface water may travel for kilometers and mixes with groundwater before being forced to the surface at distinct geomorphic knickpoints (Poole et al. 2002, 2008, Doering et al. 2007, Larned et al. 2007) to local vertical hydrologic exchange patterns where surface water infiltrates at the riffle head into sediments and exfiltrates at the riffle tail (White 1993, Brunke and Gonser 1997, Franken et al. 2001, Poole et al. 2008).

Vertical hydrologic exchange is an important physical process influencing river ecosystem properties (e.g., algal growth), processes (e.g., respiration), and biodiversity patterns (Valett et al. 1994, Jones 
1995, Malard et al. 2006, Boulton et al. 2010). For example, sediment respiration is generally higher in downwelling than in upwelling areas because organic matter derived from the infiltrating surface water fuels respiration (Jones 1995). However, in upwelling areas, algal growth is stimulated by nutrients released by the mineralization of organic matter in the hyporheic zone (Valett et al. 1994, Dahm et al. 1998, Wyatt et al. 2008).

Most studies of hyporheic flow systems have been focused at the fine scale (i.e., riffle-pool sequence), but focus has shifted recently from fine to larger scales (Datry et al. 2007). Despite a few studies in which the variability in vertical exchange and its consequence for ecosystem processes and animal behavior was considered explicitly across different spatial scales (Baxter and Hauer 2000, Dent et al. 2001, Poole et al. 2008), we have yet to understand the role of these interactions across multiple hierarchical scales (Boulton et al. 2010).

The goals of our study were to assess the effect of vertical hydrological exchange on physicochemical habitat variables, periphyton biomass, and sediment respiration at 2 spatial scales and to evaluate the extent to which regional hydrogeomorphic characteristics impose constraints at the local scale. The study system encompasses a 41.5-km-long section of a large gravel-bed river. In a $29-\mathrm{km}$-long losing reach, water continuously infiltrates into a deep porous aquifer. Major parts of this reach fall dry during base flow. In the adjacent $12.5-\mathrm{km}$-long gaining reach, some of the water infiltrated upstream emerges. Pool-run-riffle sequences representing the local scale are nested within the losing and gaining reaches at the regional scale. We expected that: 1) the regional (large scale) vertical exchange would shape ecosystem properties and processes in the losing and gaining reaches in a manner similar to what has been observed at the local riffle-pool scale in other studies, i.e., in the losing reach, we expected higher sediment respiration and lower periphyton biomass and nutrient concentrations than in the gaining reach (Valett et al. 1994, Jones et al. 1995, Wyatt et al. 2008); 2) differences in ecosystem properties and processes between riffle head (in-welling) and riffle tail (out-welling) of a pool-riffle sequence would be smaller than differences in ecosystem properties and processes between the losing and gaining reach if the vertical exchange at the regional scale dominated the effect of the vertical exchange at the local scale; 3) longitudinal expansion and contraction dynamics (drying and rewetting) would affect periphyton biomass and sediment respiration because they affect the composition, abundance, and physiology of primary producers and microbial communities (Van Gestel et al. 1993,
Clein and Schimel 1994, Stanley et al. 2004, Marxsen et al. 2010).

\section{Study system}

The Tagliamento River (lat $46^{\circ} 12^{\prime} \mathrm{N}$, long $12^{\circ} 30^{\prime} \mathrm{E}$; Fig. 1) is a $7^{\text {th }}$-order river that originates in the southern limestone Alps and flows almost unimpeded by dams for $172 \mathrm{~km}$ to the Adriatic Sea (catchment area $=2580 \mathrm{~km}^{2}$, maximum elevation $=2781 \mathrm{~m}$ asl, mean annual discharge $=90 \mathrm{~m}^{3} / \mathrm{s}$ ). The Alpine and prealpine area consist mainly of limestone and flysch, occasionally intermixed with layers of gypsum (Tockner et al. 2003). The lowland Venetian-Friulian Plain consists mainly of carbonate sediments (limestone and dolomites) that form a highly permeable and several-hundred-meter-deep aquifer (Fontana et al. 2008). Flow peaks in spring and autumn, but flow and flood pulses ( $\geq$ bankfull discharge) may occur at any time of the year (Arscott et al. 2002). The investigated river corridor along this section is up to $2 \mathrm{~km}$ wide and includes gravel (38\%), vegetated islands $(7 \%)$, riparian forest (24\%), and developed land (25\%). Detailed descriptions of the study section have been given elsewhere by Arscott et al. (2002), Tockner et al. (2003), and Doering et al. (2007).

The losing and gaining reaches we studied form a $42-\mathrm{km}$-long river section in the lowland plain. The losing reach extends from the bedrock-constrained knickpoint at river $\mathrm{km} 85$ (Pinzano) to river $\mathrm{km} \mathrm{114.} \mathrm{In}$ this losing reach, an average $2.5 \mathrm{~m}^{3} \mathrm{~s}^{-1}$ river $\mathrm{km}^{-1}$ infiltrate into the highly permeable alluvial aquifer (in total up to $70 \mathrm{~m}^{3} / \mathrm{s}$; Doering et al. 2007). At river $\mathrm{km}$ 114, the linea delle risorgive (Fig. 1), an aquiclude composed of silt and clay sediments, intersects the alluvial sediments and forces the groundwater to the surface (Fontana et al. 2008). Downstream of this knickpoint, only a small fraction of infiltrated water returns to the river bed (average exfiltration rate: $0.3 \mathrm{~m}^{3} \mathrm{~s}^{-1}$ river $\mathrm{km}^{-1}$; Fig. 2A), whereas a larger fraction of exfiltrating Tagliamento water feeds rivers that emerge along the linea delle risorgive east and west of the main stem of the Tagliamento (Doering et al. 2007). Expansion and contraction dynamics in the losing reach are linearly related to the discharge at the upstream knickpoint at river $\mathrm{km} 85$. If discharge at this location is $<60 \mathrm{~m}^{3} / \mathrm{s}$, the losing reach becomes surfacedisconnected from the gaining reach. During the dry summer of 2003, the downstream front of surface water ended at river $\mathrm{km} 91$ (Doering et al. 2007).

\section{Methods}

We assessed the effects of vertical exchange on physicochemical variables, periphyton biomass, and 


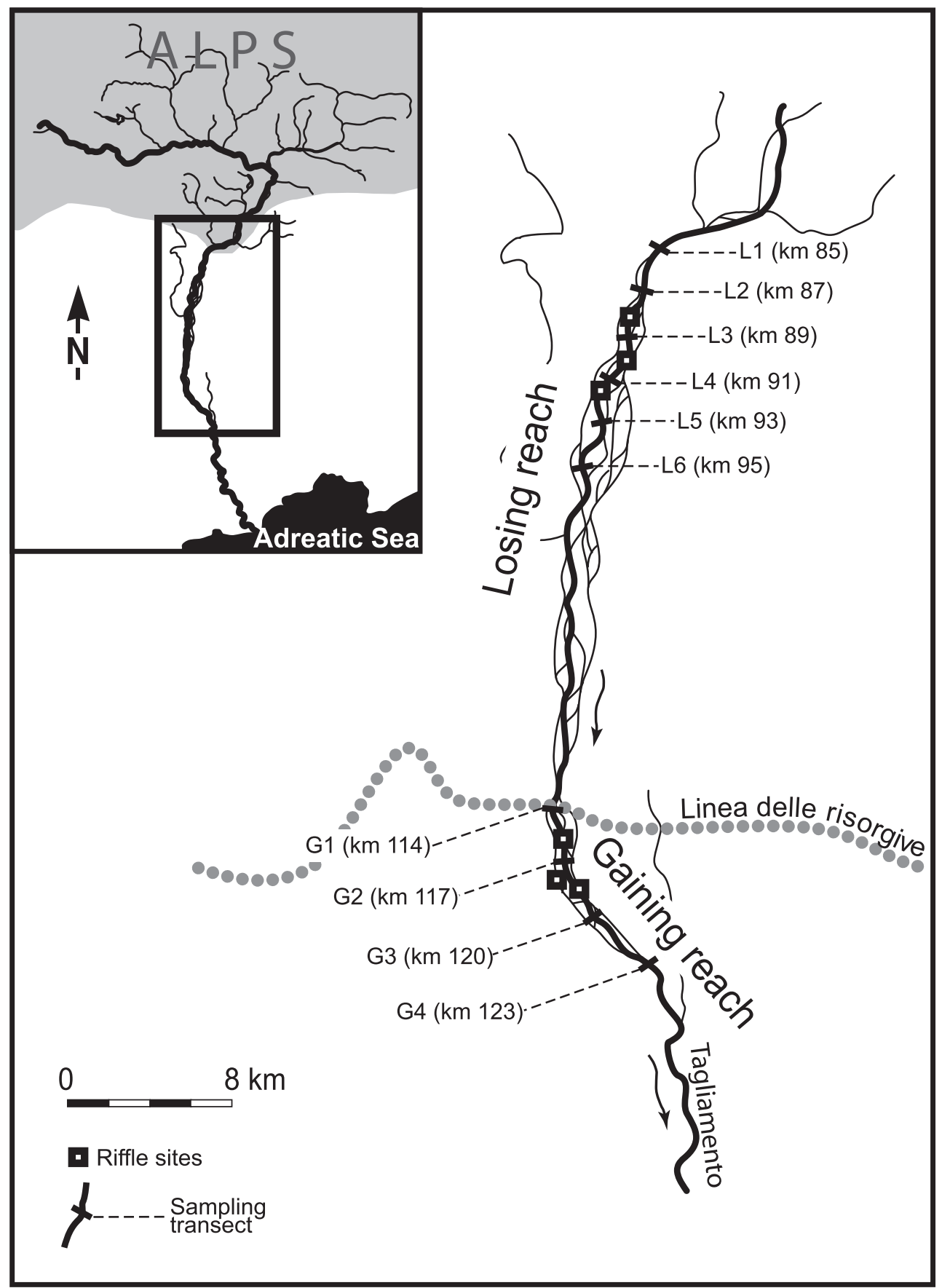

FIG. 1. Map of the study reach with transects in the losing reach (L1-L6) and gaining reach (G1-G4) sampled from July 2003 to April 2004. The open squares indicate riffle sites sampled from October 2004 to July 2005. The insert shows the study area within the drainage of the Tagliamento River.

sediment respiration at 2 nested spatial scales. At the regional scale, we sampled 6 transects in the losing and 4 transects in the gaining reaches (6 times, July 2003-April 2004). The 2 lowermost transects (L5 and L6) in the losing reach were affected by the expanding and contracting river course and mostly were dry at the surface (4 times) in summer 2003 (Fig. 1). The distance between transects was $2 \mathrm{~km}$ in the losing and $3 \mathrm{~km}$ in the gaining reach. We placed all transects in runs to minimize the effect of local vertical exchange rates at the riffle-pool scale.

At the local scale, we randomly selected 3 riffles nested in the gaining and 3 riffles nested in the losing reaches (Fig. 1). In each riffle, we sampled 1 transect 

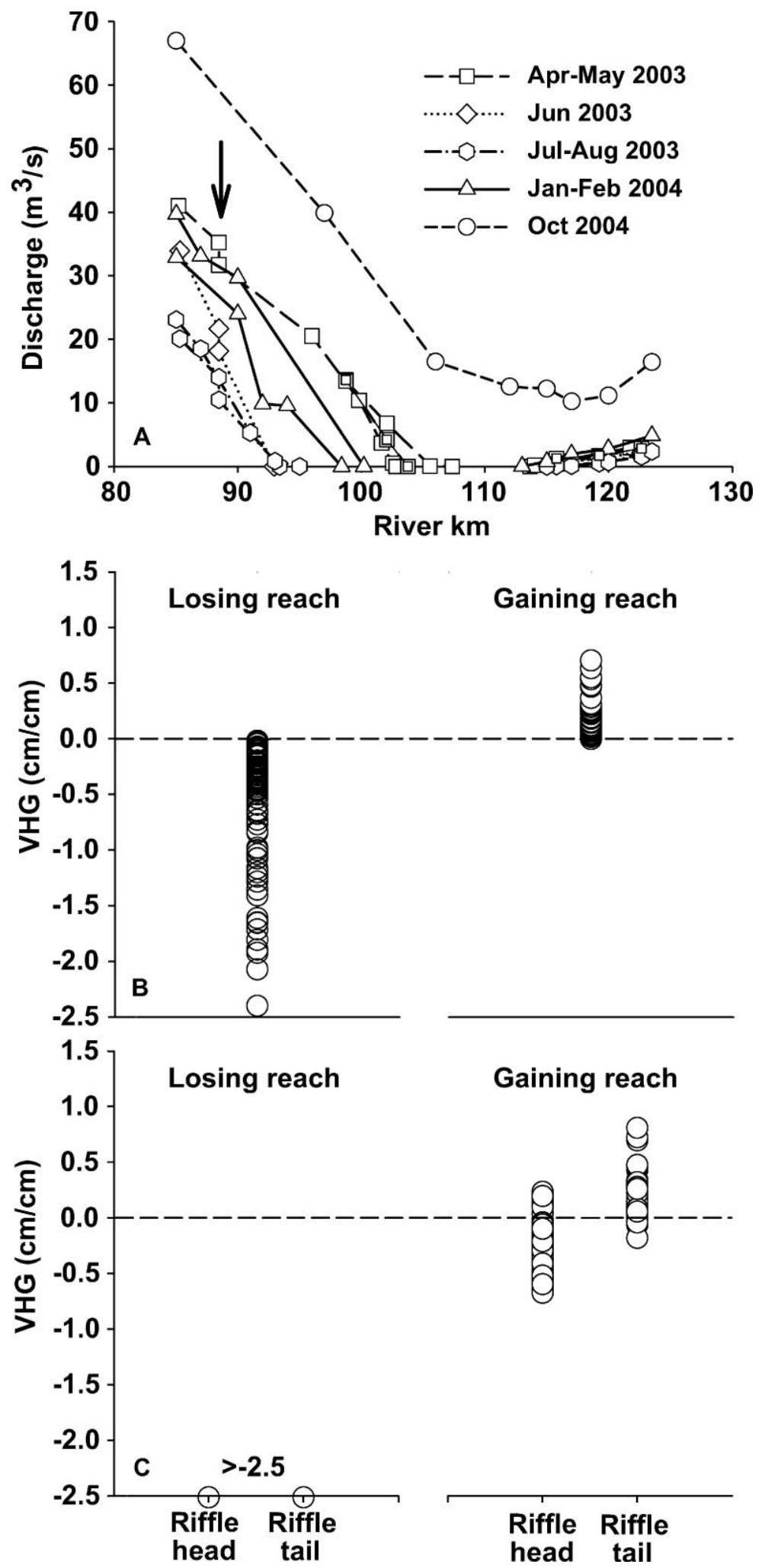

FIG. 2. A.-Surface discharge along the losing and gaining reaches (regional scale; July 2003-April 2004). The arrow marks the location of water abstraction. B.- Vertical hydraulic gradient (VHG) in the losing $(n=183)$ and gaining $(n=129)$ reaches (regional scale; July 2003-April 2004). C.-VHG at riffle heads and riffle tails in the losing (VHG $>-2.5)$ and riffle heads $(n=60)$ and riffle tails $(n=60)$ in the gaining reach (local scale; October 2004-July 2005). 
at the riffle head and 1 transect at the riffle tail 4 times from October 2004 to July 2005. The distance between riffle head and riffle tail ranged from 100 to $150 \mathrm{~m}$.

Across each transect at the regional and local scale, we measured vertical hydraulic gradient (VHG), hydrochemistry of surface and subsurface water, periphyton biomass, sediment respiration, and sediment organic matter content.

\section{Vertical hydraulic gradient (VHG) and surface discharge}

VHG characterizes groundwater-stream water exchange direction and potential intensity. VHG is defined as

$$
\mathrm{VHG}=\Delta h / \Delta l
$$

where $\Delta h$ is the difference in head between the water level in the piezometer and the level of the stream surface $(\mathrm{cm})$, and $\Delta l$ is the depth from the streambed surface to the first opening in the piezometer sidewall (Baxter et al. 2003). VHG is a dimensionless metric that is positive under upwelling and negative under downwelling conditions. We measured VHG in 5 equally spaced minipiezometers driven to a depth of $\sim 50 \mathrm{~cm}$ into the bed sediments across each transect.

We calculated infiltration and exfiltration rates $\left(\mathrm{m}^{-3} \mathrm{~s}^{-1}\right.$ river $\left.\mathrm{km}^{-1}\right)$ along the entire study area by measuring surface discharge across 7 to 13 transects with the area-velocity method and acoustic Doppler techniques (9 dates between July 2003 and October 2004). A detailed description of discharge measurements was given by Doering et al. (2007).

\section{Temperature and water chemistry}

We recorded surface-water temperature hourly at river $\mathrm{km} 88.5$ (losing reach) and river $\mathrm{km} 126.5$ (gaining reach) from August 2004 until July 2005 with temperature loggers (TR Minilog; VEMCO, Halifax, Nova Scotia). We also measured temperature at the end of each respiration experiment (spot measurements; see below).

We collected surface and interstitial water with polyethylene bottles (1 sample per date and transect). We pumped interstitial water from a depth of $\sim 50 \mathrm{~cm}$ from a piezometer in the middle of each transect. We measured conductivity of surface water and pumped interstitial water in situ with a portable conductivity meter (LF 320; WTW, Weinheim, Germany). We used analytical methods identical to those used by Tockner et al. (1997) for $\mathrm{NH}_{4}-\mathrm{N}, \mathrm{NO}_{2}-\mathrm{N}, \mathrm{NO}_{3}-\mathrm{N}$, dissolved $\mathrm{N}$ $(\mathrm{DN})$, particulate $\mathrm{N}$ and $\mathrm{P}(\mathrm{PN}, \mathrm{PP})$, soluble reactive $\mathrm{P}$ $\left(\mathrm{PO}_{4}-\mathrm{P}\right)$, dissolved $\mathrm{P}(\mathrm{DP})$, dissolved and particulate organic C (DOC, POC), and ash-free dry mass
(AFDM) of suspended solids (SS). We used analytical methods identical to those used by Malard et al. (1999) for total inorganic $\mathrm{C}$ (TIC), $\mathrm{SO}_{4}{ }^{2-}$, and $\mathrm{SiO}_{2}$. We used ion chromatography to measure $\mathrm{Cl}^{-}$and an inductively coupled emission spectrometer (SPECTRO; Analytische Geräte, Kleve, Germany) to measure $\mathrm{Ca}^{2+}, \mathrm{Mg}^{2+}, \mathrm{Na}^{+}$, and $\mathrm{K}^{+}$. We analyzed interstitial water for dissolved components only.

\section{Periphyton biomass}

We quantified periphyton biomass on 5 randomly collected rocks along each transect. We placed rocks in plastic storage bags and kept them frozen until processed. We scrubbed the rocks with a wire brush to remove algae into a bucket with water. We measured the length and width of each rock with a caliper. We filtered subsamples of the algal suspension through glass-fiber filters (Whatman GF/F) for measurement of chlorophyll $a$ (chl $a$ ) and ash-free dry mass (AFDM). We quantified chl $a$ by high-performance liquid chromatography after extraction in hot ethanol (Meyns et al. 1994). We calculated mean areal values of chl $a$ for each site as described by Uehlinger (1991).

\section{Sediment respiration and particulate organic matter (POM)}

We measured respiration of aquatic sediments as change in $\mathrm{O}_{2}$ concentration over time in Plexiglas ${ }^{\circledR}$ tubes $(5.2 \mathrm{~cm}$ diameter, $32 \mathrm{~cm}$ long) sealed with rubber stoppers (Uehlinger et al. 2002). We sampled sediments (0-20-cm sediment depth) at 3 sites along each transect after removing the uppermost sediment layer with epilithic algae. We presieved sediments to exclude particles $>8 \mathrm{~mm}$. We half-filled each tube with sediment, added water from the sampling site, and incubated the tubes in situ for $\sim 4 \mathrm{~h}$. We measured $\mathrm{O}_{2}$ concentrations and temperature with a portable $\mathrm{O}_{2}$ meter (Oxi 340/bset; WTW, Weilheim, Germany). After incubation, we kept sediments frozen until we analyzed them for organic-matter content and grain-size distribution. Based on the rate of $\mathrm{O}_{2}$ consumption in the chamber water $\left(r ; \mathrm{g} \mathrm{O}_{2}\right.$ $\mathrm{m}^{-3} \mathrm{~h}^{-1}$ ), we calculated respiration per $\mathrm{kg}$ sediment $\left(R ; \mathrm{g} \mathrm{O}_{2} \mathrm{~kg}^{-1} \mathrm{~h}^{-1}\right)$ as

$$
R=r V_{w} / G_{w}
$$

where $V_{w}$ is the volume of water in a tube $\left(\mathrm{m}^{3}\right)$ and $G_{w}$ is the mass of the sediment in the tube. We normalized respiration rates at a reference temperature of $20^{\circ} \mathrm{C}$ with the Arrhenius equation:

$$
R_{20^{\circ} \mathrm{C}}=R_{T} 1.072^{T-20^{\circ} \mathrm{C}}
$$


where $R_{20^{\circ} \mathrm{C}}$ is the respiration rate $\left(\mathrm{g} \mathrm{O}_{2} \mathrm{~kg}^{-1} \mathrm{~h}^{-1}\right)$ at $20^{\circ} \mathrm{C}$ and $\mathrm{T}$ is temperature in the tube at the end of the incubation (Naegeli and Uehlinger 1997).

\section{Sediment analysis}

We elutriated POM with deionized water (Zah 2001), and separated it by sieving into size fractions $>1,1-0.25$, and $<0.25 \mathrm{~mm}$. For the smallest fraction, we filtered an aliquot through a preweighed glassfiber filter (Whatman GF/F; diameter $=47 \mathrm{~mm}$ ). We dried POM fractions at $60^{\circ} \mathrm{C}$ for $24 \mathrm{~h}$, weighed them, combusted them at $500^{\circ} \mathrm{C}$ for $3 \mathrm{~h}$, and reweighed them. After elutriating POM, we measured the mass of the POM strongly attached to sediment particles $>0.025 \mathrm{~mm}$ (SOM) by combusting the sediments at $500^{\circ} \mathrm{C}$ for $3 \mathrm{~h}$. We expressed POM as AFDM $/ \mathrm{kg}$ sediment. We measured total $\mathrm{N}$ content of the $3 \mathrm{POM}$ fractions as $\mathrm{DN}$ and $\mathrm{PN}$ components quantified as $\mathrm{NO}_{3}-\mathrm{N}$ after digestion of filtrates with $\mathrm{K}_{2} \mathrm{~S}_{2} \mathrm{O}_{8}$ at $121^{\circ} \mathrm{C}$. We measured total dissolved $\mathrm{P}$ (TDP) as $\mathrm{PO}_{4}-\mathrm{P}$ after digestion with $\mathrm{K}_{2} \mathrm{~S}_{2} \mathrm{O}_{8}$ at $121^{\circ} \mathrm{C}$ (Ebina et al. 1983). We calculated the molar C:N ratio of different POM fractions assuming $\mathrm{C}$ content of organic matter was $50 \%$.

\section{Statistical analysis}

We $\log (x+1)$-transformed all data to meet assumptions of normality (Sokal and Rohlf 1995). We ran analyses separately for the regional-scale and the local-scale data because of the difference in sampling dates. We evaluated differences in VHG between the losing and gaining reach and between riffle heads and riffle tails with Kruskal-Wallis analyses of variance (ANOVAs). We applied 1-way ANOVAs to test for differences in $R$, periphyton chl $a$ and AFDM, and physicochemical variables among sampling sites. We used Student $t$-tests to evaluate differences in physicochemical variables, periphyton chl $a$ and AFDM, and $R$ between intermittent and permanent wetted sites (losing reach). All variables were tested separately. We subjected biogeochemical variables to principal component analysis (PCA) to assess general spatiotemporal habitat factors separating sampling sites. Frequently, chemical variables $\left(\mathrm{NH}_{4}{ }^{+}, \mathrm{NO}_{2}-\mathrm{N}\right.$, $\mathrm{PO}_{4}-\mathrm{P}$, and DP) were below detection limits of the analytical methods (Table 1) and, therefore, we excluded them from statistical analysis. We deleted data gaps on a case-wise basis. We ran all analyses with Microsoft Excel 2003 (Microsoft, Redmond, Washington) and Statistica 7.0 for Windows (StatSoft, Tulsa, Oklahoma).

\section{Results}

Regional-scale ecosystem properties and processes

VHG in runs differed between reaches (KruskalWallis, $p<0.001$ ) and averaged $-0.67 \pm 0.55$ (mean \pm $\mathrm{SD} ; n=183$ ) in the losing reach (average infiltration rate: $2.5 \mathrm{~m}^{3} \mathrm{~s}^{-1}$ river $\left.\mathrm{km}^{-1}\right)$ and $0.03 \pm 0.23(n=129)$ in the gaining reach (average exfiltration rate: $0.3 \mathrm{~m}^{3} \mathrm{~s}^{-1}$ river $\mathrm{km}^{-1}$; Fig. 2B). A detailed description of the surface discharge dynamics was given by Doering et al. (2007). Diel temperature amplitude from data loggers ranged from 0.4 to $12.6^{\circ} \mathrm{C}$ in the losing reach (river $\mathrm{km}$ 88.5) and from 0.4 to $6.2^{\circ} \mathrm{C}$ in the gaining reach (river $\mathrm{km}$ 126.5). The respective mean annual temperatures were 11.5 and $12.9^{\circ} \mathrm{C}$.

The only chemical variable that differed in concentration between surface and subsurface water was $\mathrm{SiO}_{2}$ (1-way ANOVA, $p<0.001$ ). Temperature (spot measurements) and concentrations of $\mathrm{NO}_{3}-\mathrm{N}, \mathrm{DN}$, TIC, $\mathrm{SiO}_{2}$ and $\mathrm{K}^{+}$were higher in the gaining than in the losing reach, whereas specific conductance and the concentrations of $\mathrm{O}_{2}, \mathrm{PP}, \mathrm{POC}, \mathrm{SO}_{4}{ }^{2-}, \mathrm{Cl}^{-}, \mathrm{Na}^{+}$, TSS, and AFDM were higher in the losing than in the gaining reach (1-way ANOVAs, $p<0.05$; Table 1). The molar C: $\mathrm{N}$ ratio of sediment $\mathrm{POM}>1 \mathrm{~mm}$ was higher in the losing than in the gaining reach (1-way ANOVA, $p<0.001$ ). The molar C:N ratio and $\mathrm{N}$ and $\mathrm{P}$ content of POM 1-0.025 mm were higher in the gaining than in the losing reach (1-way ANOVAs, $p \leq$ 0.007; Table 2). The PCA separated the losing and gaining reach (Fig. $3 \mathrm{~A}, \mathrm{~B}) . \mathrm{SiO}_{2}, \mathrm{POM} 1-0.025 \mathrm{~mm}$, $\mathrm{Na}^{+}, \mathrm{SO}_{4}{ }^{2-}, \mathrm{N}<0.025 \mathrm{~mm}, \mathrm{~N} 1-0.025 \mathrm{~mm}, \mathrm{P} 1-$ $0.025 \mathrm{~mm}$, and $\mathrm{O}_{2}$ accounted for most of the definition of axis $\mathrm{F} 1$ (factor loadings $\geq 60 \%$ ). $\mathrm{P}<0.025 \mathrm{~mm}$, TSS, $\mathrm{POM}<0.025 \mathrm{~mm}, \mathrm{Mg}^{2+}$, and conductivity accounted for most of the definition of axis F2 (factor loadings $\geq 60 \%$ ).

Concentrations of chl $a$ were $19.7 \pm 33.7 \mathrm{mg} / \mathrm{m}^{2}$ in the losing reach and $20.1 \pm 33.2 \mathrm{mg} / \mathrm{m}^{2}$ in the gaining reach and did not differ between reaches (1-way ANOVA, $p>0.05$; Fig. 4A). Periphyton AFDM was significantly lower in the losing $\left(12.0 \pm 12.2 \mathrm{~g} / \mathrm{m}^{2}\right)$ than in the gaining reach $\left(21.3 \pm 18.9 \mathrm{~g} / \mathrm{m}^{2}\right)(1$-way ANOVA, $p<0.001$; Fig. $4 \mathrm{~B}$ ). $R_{20^{\circ} \mathrm{C}}$ was significantly higher in the losing $\left(0.42 \pm 0.19 \mathrm{mg} \mathrm{O}_{2} \mathrm{~kg}^{-1}\right.$ sediment $\left.\mathrm{h}^{-1}\right)$ than in the gaining reach $\left(0.26 \pm 0.15 \mathrm{mg} \mathrm{O}_{2} \mathrm{~kg}^{-1}\right.$ sediment $\mathrm{h}^{-1}$ ) (1-way ANOVA, $p<0.001$; Fig. 4C).

Chl $a$ and periphyton AFDM differed between permanent (L1-L4) and intermittent (L5, L6) sites in the losing reach (Fig. 1) ( $t$-tests, $p \leq 0.001$; permanent sites: $12.1 \pm 25.6 \mathrm{mg} \mathrm{chl} a / \mathrm{m}^{2}$ and $7.1 \pm 10.1 \mathrm{~g}$ AFDM/ $\mathrm{m}^{2}$; intermittent sites: $7.9 \pm 11.3 \mathrm{mg} \mathrm{chl} a / \mathrm{m}^{2}$ and $5.8 \pm$ $4.2 \mathrm{~g} \mathrm{AFDM} / \mathrm{m}^{2}$ ). Temperature (spot measurements), chemical variables, POM, and sediment respiration did 
TABLE 1. Mean ( \pm 1 SD) physicochemical variables in the losing (LR) and gaining (GR) reaches, and pooled data from riffle heads and riffle tails in the losing (RLR) and gaining (RGR) reaches. Significant differences between LR and GR and between RLR and RGR are indicated in bold. * indicates values only from surface-water samples.

\begin{tabular}{|c|c|c|c|c|}
\hline Variable & $\begin{array}{c}\text { LR } \\
n=56\end{array}$ & $\begin{array}{c}\text { GR } \\
n=48\end{array}$ & $\begin{array}{c}\text { RLR } \\
n=24^{*}\end{array}$ & $\begin{array}{c}\text { RGR } \\
n=48\end{array}$ \\
\hline Temperature $\left({ }^{\circ} \mathrm{C}\right)$ & $15.3 \pm 4.97$ & $17.3 \pm 5.4$ & $13.5 \pm 7.41$ & $15.1 \pm 4.72$ \\
\hline Specific conductance $(\mu S / \mathrm{cm})$ & $559.9 \pm 39.2$ & $513.1 \pm 50.9$ & $562.2 \pm 35.1$ & $477.8 \pm 37.9$ \\
\hline $\mathrm{NH}_{4}-\mathrm{N}(\mathrm{mg} / \mathrm{L})$ & $<0.001$ & $<0.001$ & $<0.001$ & $<0.001$ \\
\hline $\mathrm{NO}_{2}-\mathrm{N}(\mathrm{mg} / \mathrm{L})$ & $<0.001$ & $<0.001$ & $<0.001$ & $<0.001$ \\
\hline Particulate $\mathrm{N}(\mathrm{mg} / \mathrm{L})^{*}$ & $0.02 \pm 0.02$ & $0.01 \pm 0.01$ & $6.50 \pm 11.60$ & $2.47 \pm 5.00$ \\
\hline $\mathrm{PO}_{4}-\mathrm{P}(\mu \mathrm{g} / \mathrm{L})$ & $<5$ & $<5$ & $<5$ & $<5$ \\
\hline Dissolved P $(\mu \mathrm{g} / \mathrm{L})$ & $<5$ & $<5$ & $<5$ & $<5$ \\
\hline Particulate P $(\mu \mathrm{g} / \mathrm{L})^{*}$ & $2.65 \pm 2.26$ & $1.70 \pm 2.28$ & $4.80 \pm 4.71$ & $2.11 \pm 1.46$ \\
\hline Dissolved organic C $(\mathrm{mg} / \mathrm{L})$ & $0.80 \pm 0.26$ & $0.73 \pm 0.35$ & $0.64 \pm 0.16$ & $0.41 \pm 0.21$ \\
\hline Total inorganic $\mathrm{C}(\mathrm{mg} / \mathrm{L})$ & $35.0 \pm 4.29$ & $39.7 \pm 10.8$ & $28.1 \pm 4.97$ & $35.4 \pm 3.94$ \\
\hline Particulate organic $C(\mathrm{mg} / \mathrm{L})^{*}$ & $0.50 \pm 0.34$ & $0.22 \pm 0.14$ & $0.98 \pm 0.89$ & $0.32 \pm 0.23$ \\
\hline $\mathrm{Mg}^{2+}(\mathrm{mmol} / \mathrm{L})$ & $19.9 \pm 1.33$ & $20.1 \pm 2.63$ & $19.9 \pm 1.55$ & $19.4 \pm 1.43$ \\
\hline $\mathrm{K}^{+}(\mathrm{mg} / \mathrm{L})$ & $1.03 \pm 0.16$ & $1.13 \pm 0.28$ & $1.12 \pm 0.20$ & $1.28 \pm 0.47$ \\
\hline $\mathrm{Na}^{+}(\mathrm{mg} / \mathrm{L})$ & $3.39 \pm 0.41$ & $3.00 \pm 0.38$ & $3.37 \pm 0.53$ & $2.93 \pm 0.43$ \\
\hline Total suspended solids (mg/L) & $4.10 \pm 4.29$ & $1.65 \pm 1.70$ & $2.54 \pm 3.82$ & $1.39 \pm 2.07$ \\
\hline Ash-free dry mass $(\mathrm{mg} / \mathrm{L})^{*}$ & $2.89 \pm 1.07$ & $1.94 \pm 0.91$ & $3.55 \pm 1.44$ & $2.95 \pm 0.93$ \\
\hline
\end{tabular}

not differ between permanent and intermittent sites in the losing reach.

Local-scale ecosystem properties and processes in the losing and gaining reaches

In the losing reach, piezometers were dry beneath the wetted surface, i.e., VHG was more negative than the difference in piezometer depth $(>-2.5)$ and could not be quantified. In the gaining reach, VHG was more negative at the riffle heads $(-0.20 \pm 0.24, n=$ $60)$ than at the riffle tails $(0.18 \pm 0.19, n=60$; Fig. $2 \mathrm{C})$ (Kruskal-Wallis, $p<0.001$ ).

Temperature (spot measurements), chemical variables, and POM (Tables 1, 2) did not differ between riffle heads and riffle tails in the losing or gaining reaches (1-way ANOVAs, $p>0.05)$. PCA only slightly separated riffle heads and riffle tails but strongly separated the losing and gaining reaches (Fig. 3C, D). Axis F1 was mostly defined by $\mathrm{SO}_{4}{ }^{2-}$, conductivity, $\mathrm{NO}_{3}-\mathrm{N}, \mathrm{DN}, \mathrm{Na}^{+}, \mathrm{Ca}^{2+}, \mathrm{PP}, \mathrm{SiO}_{2}$, and POC (factor loadings $\geq 60 \%$ ). Axis F2 was mostly defined by P 1-0.025 mm, N 1-0.025 mm, N >1 mm, $\mathrm{C}: \mathrm{N}$ ratio $1-0.025 \mathrm{~mm}, \mathrm{P}>1 \mathrm{~mm}, \mathrm{C}: \mathrm{N}$ ratio $<0.025$, and TSS (factor loadings $\geq 60 \%$ ).

Chl $a$, periphyton AFDM, and $R_{20^{\circ} \mathrm{C}}$ did not differ between riffle heads and riffle tails in the losing or gaining reaches. In the losing reach, chl $a$, periphyton
AFDM, and $R_{20^{\circ} \mathrm{C}}$ averaged $15.1 \pm 20.8 \mathrm{mg} \mathrm{chl} \mathrm{a} / \mathrm{m}^{2}$, $10.3 \pm 9.18 \mathrm{~g} \mathrm{AFDM} / \mathrm{m}^{2}$, and $0.46 \pm 0.36 \mathrm{mg} \mathrm{O}_{2} \mathrm{~kg}^{-1}$ sediment $\mathrm{h}^{-1}$ at riffle heads and $10.5 \pm 16.8 \mathrm{mg} \mathrm{chl} \mathrm{a/}$ $\mathrm{m}^{2}, 14.1 \pm 15.8 \mathrm{~g} \mathrm{AFDM} / \mathrm{m}^{2}$, and $0.48 \pm 0.34 \mathrm{mg} \mathrm{O}$ $\mathrm{kg}^{-1}$ sediment $\mathrm{h}^{-1}$ at riffle tails (1-way ANOVA, $p>$ 0.05; Fig. 4D-F). In the gaining reach, chl $a$, AFDM, and sediment respiration averaged $31.4 \pm 56.6 \mathrm{mg} \mathrm{chl} a / \mathrm{m}^{2}$, $17.3 \pm 23.3 \mathrm{~g} \mathrm{AFDM} / \mathrm{m}^{2}$, and $0.35 \pm 0.15 \mathrm{mg} \mathrm{O}_{2} \mathrm{~kg}^{-1}$ sediment $\mathrm{h}^{-1}$ at riffle heads and $30.2 \pm 65.2 \mathrm{mg} \mathrm{chl} \mathrm{a/}$ $\mathrm{m}^{2}, 19.1 \pm 12.2 \mathrm{~g} \mathrm{AFDM} / \mathrm{m}^{2}$, and $0.24 \pm 0.12 \mathrm{mg} \mathrm{O}$ $\mathrm{kg}^{-1}$ sediment $\mathrm{h}^{-1}$ at riffle tails (1-way ANOVA, $p>$ 0.05; Fig. 4D-F).

Comparisons of physicochemical variables, chl $a$, AFDM, and $R_{20^{\circ} \mathrm{C}}$ between riffle heads and riffle tails in the losing reach with values in riffle heads and riffle tails nested in the gaining reach yielded almost the same pattern as observed at the regional scale (Table 1, Fig. 4G-I). $R_{20^{\circ} \mathrm{C}}$ was related to chl $a$ and periphyton AFDM (chl $a: R^{2} \leq 0.23, p<0.046$; AFDM: $\left.R^{2} \leq 0.49, p<0.036\right)$ but not to sediment organic matter $(p \geq 0.068)$.

\section{Discussion}

We quantified the effect of vertical exchange on ecosystem properties and processes at 2 spatial scales along the large gravel-bed Tagliamento River. At the 
TAble 2. Mean ( $\pm 1 \mathrm{SD}$ ) biomass (mg ash-free dry mass [AFDM] $/ \mathrm{kg}$ sediment), $\mathrm{N}(\mu \mathrm{g} \mathrm{N} / \mathrm{kg}$ sediment), $\mathrm{P}$ ( $\mu \mathrm{g} \mathrm{P} / \mathrm{kg}$ sediment), and molar C:N ratio of particulate organic matter (POM) in 3 different size fractions $(>1 \mathrm{~mm}, 1-0.25 \mathrm{~mm},<0.25 \mathrm{~mm})$ and POM strongly attached to sediment particles $>0.025 \mathrm{~mm}$ (SOM; g/ kg sediment). Data are shown for the losing (LR) and gaining (GR) reaches and as pooled data for riffle heads and riffle tails in the losing (RLR) and gaining (RGR) reaches. Significant values are highlighted in bold.

\begin{tabular}{|c|c|c|c|c|}
\hline Site & $\begin{array}{c}\text { LR } \\
n=84\end{array}$ & $\begin{array}{c}\text { GR } \\
n=72\end{array}$ & $\begin{array}{c}\text { RLR } \\
n=72\end{array}$ & $\begin{array}{c}\text { RGR } \\
n=72\end{array}$ \\
\hline \multicolumn{5}{|c|}{$\mathrm{POM}>1 \mathrm{~mm}$} \\
\hline $\mathrm{N}$ & $866.3 \pm 1074$ & $1201 \pm 1857$ & $1005 \pm 1371$ & $1099 \pm 1396$ \\
\hline $\mathrm{C}: \mathrm{N}$ & $51.8 \pm 23.1$ & $38.3 \pm 30.0$ & $39.3 \pm 42.45$ & $37.5 \pm 36.2$ \\
\hline $\mathrm{P}$ & $46.2 \pm 82.5$ & $72.4 \pm 148.0$ & $68.1 \pm 122.4$ & $46.6 \pm 59.6$ \\
\hline \multicolumn{5}{|c|}{ POM 1-0.025 mm } \\
\hline $\mathrm{N}$ & $3544 \pm 5549$ & $6608 \pm 8289$ & $3082 \pm 4612$ & $3452 \pm 4978$ \\
\hline $\mathrm{C}: \mathrm{N}$ & $31.5 \pm 57.8$ & $32.6 \pm 29.3$ & $120.5 \pm 258.6$ & $131.1 \pm 288.9$ \\
\hline $\mathrm{P}$ & $791.0 \pm 1131.5$ & $1260 \pm 1461$ & $1302 \pm 2824$ & $955 \pm 1284$ \\
\hline \multicolumn{5}{|c|}{$\mathrm{POM}<0.025 \mathrm{~mm}$} \\
\hline AFDM & $872.4 \pm 585.0$ & $923.0 \pm 620.0$ & $912.2 \pm 505.7$ & $990.5 \pm 572.2$ \\
\hline
\end{tabular}

regional scale, physicochemical variables, chl $a$, periphyton AFDM, and $R_{20^{\circ} \mathrm{C}}$ reflected vertical-exchange patterns in losing and gaining reaches similar to those observed in other river systems at the small (rifflepool) scale. At the local scale, i.e., at riffle heads and riffle tails nested in the losing and gaining reach, variables did not respond to vertical exchange. However, averaged data for riffle heads and riffle tails in the losing reach compared to averaged data for riffle heads and riffle tails in the gaining reach revealed almost the same pattern of response to vertical exchange as observed at the regional scale. Chl $a$ and periphyton AFDM showed negative responses to drying and rewetting conditions within the expanding and contracting losing reach.

An integrative view of ecosystem properties and processes at different spatial scales

At the regional scale, the losing reach was characterized by a substantial loss of surface flow into the highly permeable and deep alluvium that led to rapid expansion and contraction dynamics. The average infiltration rate of $2.5 \mathrm{~m}^{3} \mathrm{~s}^{-1}$ river $\mathrm{km}^{-1}$ was comparable to the rates observed in the Middle Fork of the Flathead River (Montana; $1.3 \mathrm{~m}^{3} \mathrm{~s}^{-1}$ river $\mathrm{km}^{-1}$; Stanford et al. 2005) and Homestead Creek (Australia; $1.1 \mathrm{~m}^{3} \mathrm{~s}^{-1}$ river $\mathrm{km}^{-1}$; Dunkerley and Brown 1999). Doering et al. (2007) showed that average infiltration rates per river $\mathrm{km}$ in the losing reach (Tagliamento) were independent of the discharge measured at the upstream end of the reach (for discharge range 20$70 \mathrm{~m}^{3} / \mathrm{s}$ ). In the gaining reach, the exfiltration rate was, on average, only $0.3 \mathrm{~m}^{3} \mathrm{~s}^{-1}$ river $\mathrm{km}^{-1}$ because most of the upstream infiltrated river water emerges outside of the Tagliamento River corridor and feeds numerous springs (Fontana et al. 2008). Thus, average vertical hydraulic gradient (VHG) was highly negative in the losing reach but only slightly positive in the gaining reach (Fig. 2B).

At the local scale, along the losing reach, an $\sim 0.5-$ m-deep saturated sediment layer covered an unsaturated layer between the stream bed and the shallow water table (perched hyporheic zone). Similar conditions have been reported for the upper proglacial Val Roseg floodplain (Switzerland) where only the uppermost 20 to $40 \mathrm{~cm}$ of the sediments were saturated (Malard et al. 2000, 2002). In our study reaches, ground water was not reached until a depth of $1.7 \mathrm{~m}$ below the bed surface, although within $10 \mathrm{~cm}$ of the shoreline in the wetted channel area. Duration and magnitude of floods influence sediment permeability of bed sediments (Dunkerley and Brown 1999, Gasith and Resh 1999, Doering et al. 2007) and presumably depth and vertical extent of the saturated reach. We lack direct evidence from VHG measurements in the losing reach of the Tagliamento, but we hypothesize that at the local scale in the losing reach, downwelling marginalizes or prevents local upwelling (e.g., at riffle tails). In the gaining reach, VHG indicated approximately equal intensity 

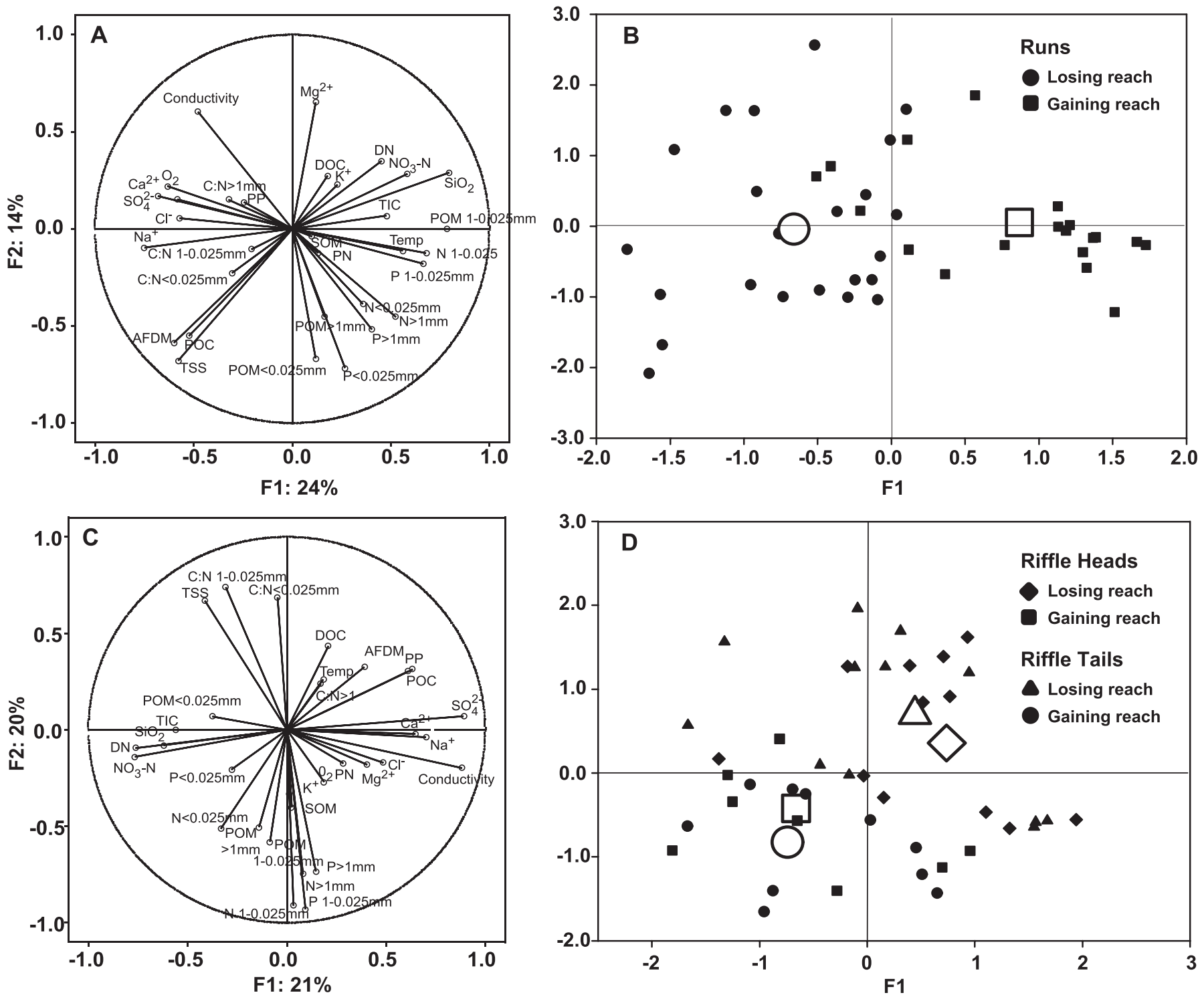

FIG. 3. Principal components analysis of physicochemical variables excluding subsurface hydrochemical data (see text) showing the correlation circle (A) and factor map (axes F1 and F2; percentages are \% variance explained) (B) for physicochemical variables sampled in runs from July 2003 to April 2004 in the losing and gaining reach, and correlation circle (C) and factor map (D) for physicochemical variables, excluding subsurface hydrochemical data, sampled from October 2004 to July 2005 at riffle heads and riffle tails in the losing reach and at riffle heads and riffle tails in the gaining reach. Large open symbols represent centroids of respective sites. AFDM = ash-free dry mass, DN = dissolved $\mathrm{N}, \mathrm{DP}$ dissolved $\mathrm{P}, \mathrm{PN}=$ particulate $\mathrm{N}, \mathrm{POC}=$ particulate organic $\mathrm{C}, \mathrm{POM}=$ particulate organic matter (size classes: $>1 \mathrm{~mm}, 0.025-1 \mathrm{~mm},<0.025 \mathrm{~mm}$ ), $\mathrm{PP}=$ particulate $\mathrm{P}, \mathrm{SOM}$ $=$ soluble organic matter, Temp $=$ temperature, TIC $=$ total inorganic $\mathrm{C}, \mathrm{TOC}=$ total organic $\mathrm{C}$, TSS $=$ total suspended solids.

of down- and upwelling at riffle heads and riffle tails, respectively. In contrast to the losing reach, the hydrogeomorphic settings apparently impose minor constraints on local vertical exchange.

Overall, physicochemical habitat variables differed between the losing and gaining reaches (regional scale) but not between riffle heads and riffle tails (local scale). Changes in water chemistry are apparently related to the length of the subsurface flow path and discharge. They were evident at the regional scale, but discharge was too high and flow paths too short to exert a major influence on the chemical milieu at the local scale. In gravel-bed rivers, flow paths are not isolated (Poole et al. 2008). Surface water mixing with shallow hyporheic and phreatic ground waters from long flow paths at the regional scale may result in water chemistry in upwelling locations influenced mainly by water composed of many different ages 

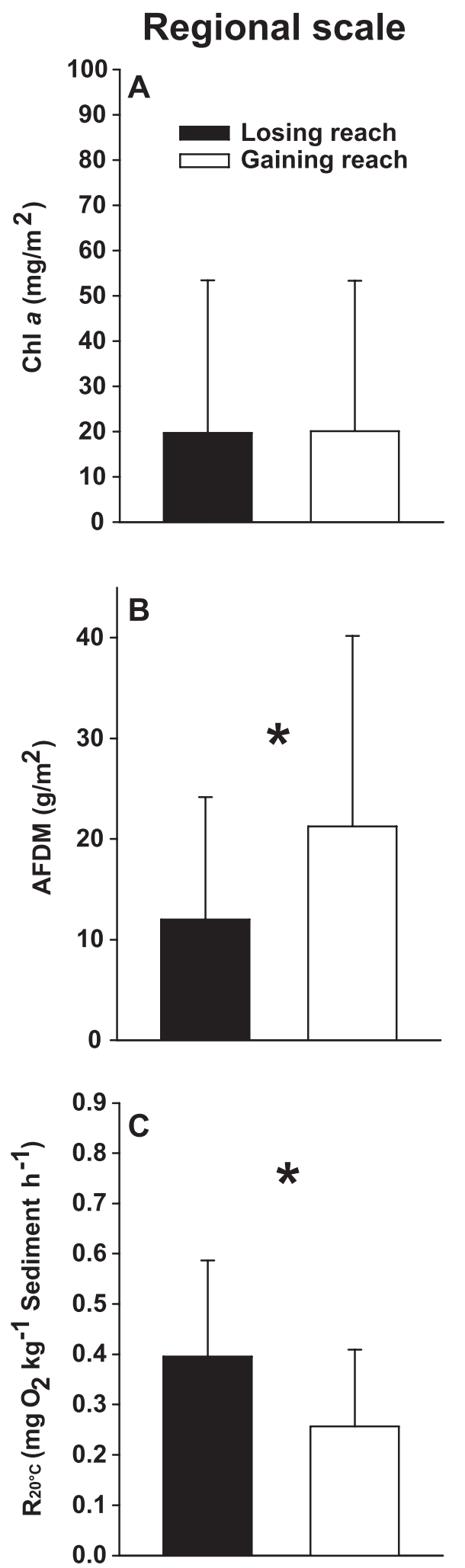

Local scale

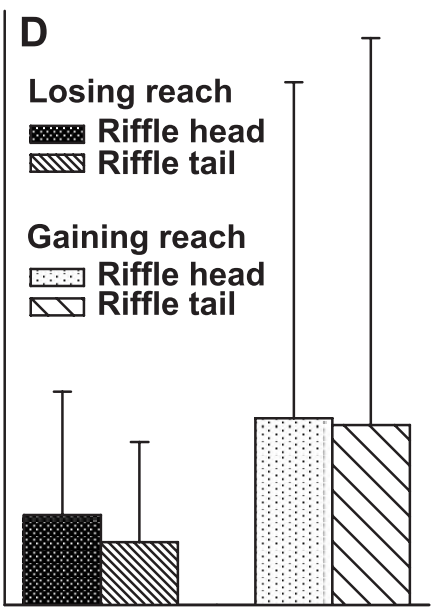

E

Pooled data
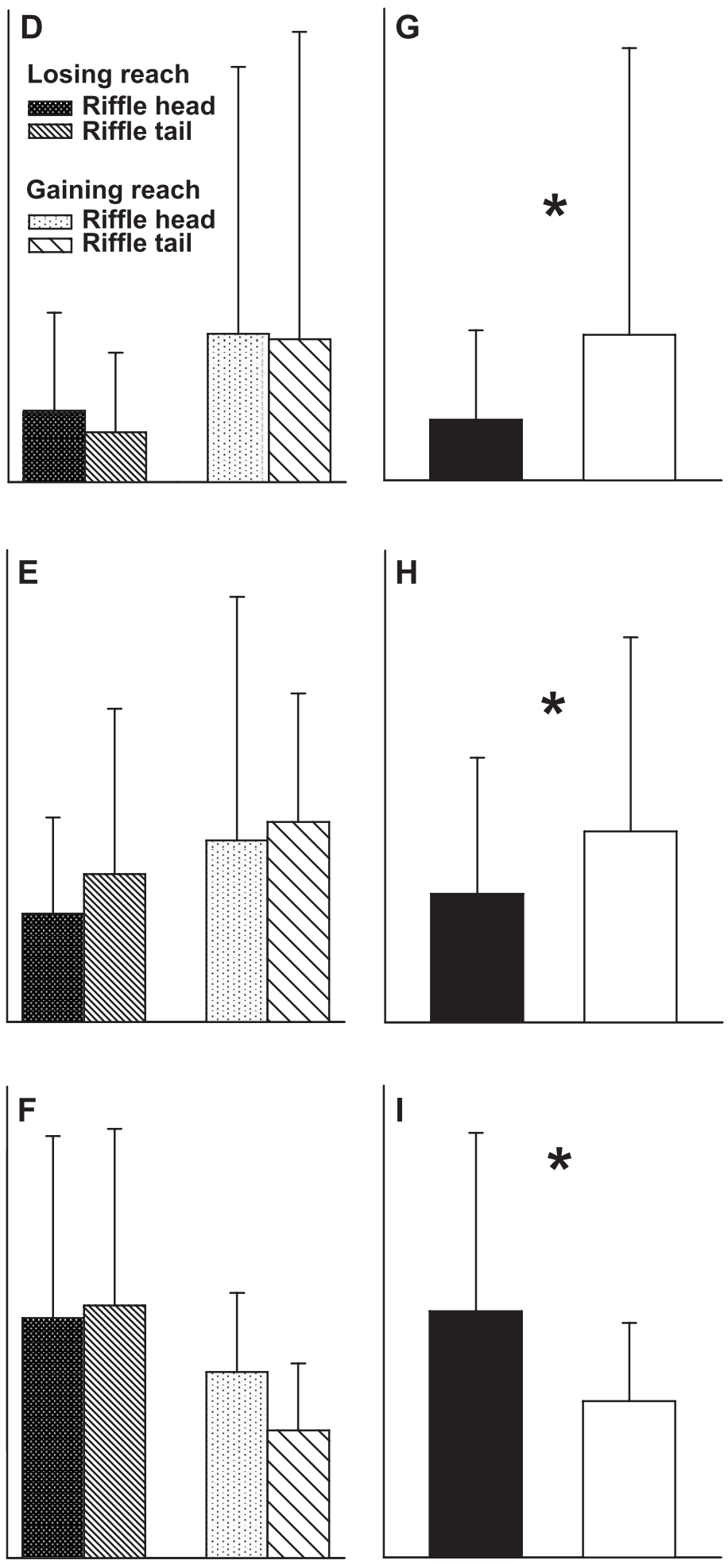

Fig. 4. Mean ( $\pm 1 \mathrm{SD})$ chlorophyll $a(\mathrm{chl} a)(\mathrm{A}, \mathrm{D}, \mathrm{G})$, periphyton ash-free dry mass (AFDM) (B, E, H), and hyporheic respiration per $\mathrm{kg}$ sediment particles $<8 \mathrm{~mm}$ normalized to $20^{\circ} \mathrm{C}\left(R_{20^{\circ}} \mathrm{C}\right)(\mathrm{C}, \mathrm{F}, \mathrm{I})$ in runs of the losing and gaining reach at the regional scale (July 2003-April 2004) (A-C), in riffle heads and riffle tails of the losing and gaining reach at the local scale (October 2004-July 2005) (D-F), and pooled data for riffle heads and riffle tails in the losing and gaining reach (G-I). Asterisks mark significant differences. 
rather than by biogeochemical processes acting over time along a short flow path. In small streams, local vertical or lateral vertical exchange may strongly influence surface-water chemistry, in particular nutrient concentrations (e.g., Hendricks 1993, Valett et al. 1994, Dahm et al. 1998, Dent et al. 2001). For example, in Sycamore Creek (Arizona, USA), surface $\mathrm{NO}_{3}{ }^{-}$ concentrations were 2 to $3 \times$ higher in local upwelling areas than in corresponding downwelling reaches (Valett et al. 1994). In general, downwelling areas are locations where suspended organic matter is expected to be retained in the uppermost sediments and subsequently processed. In the Tagliamento, differences in sediment organic matter between down- and upwelling areas were not significant at the regional or local scale and corresponded to a low POM load during base flow. Retained POM, such as sloughed algae, is presumably subject to fast decomposition. In particular, POM loads during floods are retained in downwelling areas. Jones et al. (1995) found that sediment POC was higher in downwelling than in upwelling areas after floods in Sycamore Creek, but these differences disappeared during interspate periods. This result suggests that floods, rather than the continuous POM supply during base flow, may account for differences in sediment organic matter between downand upwelling areas.

Upwelling can enhance periphyton accrual (e.g., chl $a$ is positively correlated with VHG). This effect has been demonstrated at the riffle-pool scale (100-140 m) in a small desert stream (Valett et al. 1994) and at a larger scale (500-1000 m) in a medium-sized floodplain river (Stanford et al. 2005, Wyatt et al. 2008). At the regional scale in the Tagliamento, periphyton AFDM was significantly higher in the gaining than in the losing reach, but did not differ between riffle heads and riffle tails (both reaches) at the local scale. The spatial pattern of chl $a$ was quite different. No difference was observed between reaches at the regional scale, but distinct differences between losing and gaining reaches in pooled data from riffle heads and riffle tails were found at the local scale. Enhanced nutrient availability in riffle heads and riffle tails of the gaining reach may account for the observed higher chl $a$ content of the periphyton community in the gaining reach. However, chl $a$ is less suitable than periphyton AFDM as a biomass variable because the chlorophyll content of algae depends on environmental conditions. The chlorophyll content of algae can decline with increasing $\mathrm{N}$ or $\mathrm{P}$ limitation (Healey and Hendzel 1975, Rhee 1978, Uehlinger 1981) and with decreasing light intensity (Hill and Boston 1991). Both chl $a$ and AFDM were higher at permanently wetted sites. Fast contraction-expansion cycles triggered by local convective rain events limit primary producers from developing desiccant-resistant structures or physiological adjustment. During flow recession, the downstream end of the wetted channel in the losing reach may move upstream at rates as high as 0.5 $\mathrm{km} / \mathrm{h}$ (Doering et al. 2007). Algae are expected to die within hours after they fall dry (Agrawal and Singh 2002, Stanley et al. 2004).

At the regional scale, vertical exchange was apparently a major factor controlling sediment respiration. At the local scale, differences between downwelling and corresponding upwelling areas were not significant, although $R_{20^{\circ} \mathrm{C}}$ tended to be slightly higher at riffle heads than at riffle tails (Fig. 4F). The correlations between $R_{20^{\circ} \mathrm{C}}$, chl $a$, and periphyton AFDM indicate that autochthonous production of organic matter, which includes release of extracellular organic matter by algae and sloughed algal cells, may be an important energy source fueling sediment respiration (Jones et al. 1995). In the wide, braided channel of the Tagliamento, allochthonous inputs from riparian forests and upstream areas presumably are of minor importance as an energy source for aquatic communities (Langhans et al. 2006). In desert streams, autochthonous energy supply can support $>80 \%$ of the respiration in the hyporheic reach (Jones et al. 1995), whereas in forested streams, allochthonous organic matter input serves as the primary energy source (Pusch and Schwoerbel 1994, Naegeli et al. 1995). Respiration rates were several times higher in the Tagliamento than in the Alpine floodplain of the Roseg River but 2 to $3 \times$ times lower than in desert streams (Table 3 ), a pattern that is most likely a function of temperature and the source and quality of organic matter as described above.

\section{Conclusion}

Our results supported our expectations. The observed spatial pattern in ecosystem properties and processes at the regional, large scale in the losing and gaining reach of the Tagliamento River matches findings from other investigations at the scale of channel bedform units (riffle-pool) (e.g., high biomass in upwelling areas and high respiration in downwelling areas; Valett et al. 1994, Jones et al. 1995). Vertical exchange was apparently a major factor controlling ecosystem properties and ecosystem processes across spatial scales. High infiltration and exfiltration rates at the regional scale impose constraints on the vertical exchange at the local, small scale (riffle-pool). Furthermore, relatively high discharge (e.g., 5-60 $\mathrm{m}^{3} / \mathrm{s}$ at river $\mathrm{km} \mathrm{91),} \mathrm{including} \mathrm{potential}$ mixing of surface, phreatic, and hyporheic groundwater, presumably reduced the effect of nutrient regen- 
TABLE 3. Mean ( $\pm 1 \mathrm{SD})$ respiration rates in hyporheic sediments $(0.1 \mathrm{~m}$ sediment depth) of the Tagliamento River compared to rates in other streams (Jones et al. 1995, Uehlinger et al. 2002, Uehlinger and Zah 2003). All respiration rates were quantified in respiration chambers at a depth of $0.1 \mathrm{~m}$.

\begin{tabular}{lr}
\hline \hline \multicolumn{1}{c}{ River } & $\begin{array}{c}\text { Respiration } \\
\left(\mathrm{mg} \mathrm{O}_{2} \mathrm{~kg}^{-1} \mathrm{~h}^{-1}\right)\end{array}$ \\
\hline Tagliamento (Italy; low elevation Alpine floodplain; July 2003-June 2005; monthly average rate) & $0.42 \pm 0.19$ \\
$\quad$ Losing reach & $0.26 \pm 0.15$ \\
Gaining reach & $0.02 \pm 0.02$ \\
Val Roseg (Switzerland; high elevation Alpine floodplain; March-October; monthly average rate) & $0.04 \pm 0.03$ \\
Main channel & $0.08 \pm 0.06$ \\
Surface connected channels & 1.12 \\
Surface-disconnected channels & 0.46 \\
Sycamore Creek (USA; desert stream; annual mean rate) & $0.96 \pm 0.11$ \\
Downwelling zones & \\
Upwelling zones & \\
Hassayampa River (desert stream; autumn) & \\
\hline
\end{tabular}

eration along the relatively short subsurface flow path between riffle heads and riffle tails. Both factors are finally responsible for the lack of response in ecosystem properties and ecosystem processes at the local scale. Expansion and contraction dynamics (drying and rewetting) affected periphyton accrual negatively as shown in other studies (Stanley et al. 2004). We demonstrated the hierarchical nature of floodplain systems with respect to vertical exchange, ecosystem properties, and ecosystem processes across different spatial scales. These hierarchical scales cannot be uncoupled, and understanding their interaction is essential in understanding the function and complexity of riverine ecosystems.

\section{Acknowledgements}

We are very grateful to the many people who helped in the field and with logistics, especially C. Cruciat, S. Blaser, and Y. Schwill, and C. T. Robinson for comments on earlier versions of this manuscript. The comments of 3 referees improved the manuscript. This work was supported by the European Union project tempQsim (EVK1-CT2002-00112; www. tempqsim.net) and by the Staatssekretariat für Bildung und Forschung (SBF) (No. 02.0072).

\section{Literature Cited}

ACUÑA, V., AND K. TOCKNER. 2009. Surface-subsurface water exchange rates along alluvial river reaches control the thermal patterns in an Alpine river network. Freshwater Biologv 54:306-320.

Agrawal, S. C., AND V. Singh. 2002. Viability of dried filaments, survivability and reproduction under water stress, and survivability following heat and UV exposure in Lyngbya martensiana, Oscillatoria agardhii, Nostoc calcicola, Hormidium fluitans, Spirogyra sp., and Vaucheria germinata. Folia Microbiologica 47:61-67.

Arscott, D. B., K. TOCKNer, D. van DER NAT, AND J. V. WARD. 2002. Aquatic habitat dynamics along a braided alpine river ecosystem (Tagliamento River, Northeast Italy). Ecosystems 5:802-814.

BAXTer, C., AND F. R. Hauer. 2000. Geomorphology, hyporheic exchange, and selection of spawning habitat by bull trout (Salvelinus confluentus). Canadian Journal of Fisheries and Aquatic Sciences 57:1470-1481.

Baxter, C., F. R. Hauer, And W. W. Woessner. 2003. Measuring groundwater-stream water exchange: new techniques for installing minipiezometers and estimating hydraulic conductivity. Transactions of the American Fisheries Societv 132:493-503.

Boulton, A. J., T. Datry, T. Kasahara, M. Mutz, and J. A. STANFORD. 2010. Ecology and management of the hyporheic zone: stream-groundwater interactions of running waters and their floodplains. Iournal of the North American Benthological Societv 29:26-40.

BRUNKE, M., AND T. GONSER. 1997. The ecological significance of exchange processes between rivers and groundwater. Freshwater Biology 37:1-33.

Clein, J. S., AND J. P. Schimel. 1994. Reduction in microbial activity in birch litter due to drying and rewetting events. Soil Biology and Biochemistry 26:403-406.

Dahm, C. N., N. B. Grimm, P. Marmonier, H. M. Valett, And P. Vervier. 1998. Nutrient dynamics at the interface between surface water and groundwaters. Freshwater Biology 40:427-452.

Datry, T., S. T. LARnED, AND M. R. ScARSBROOK. 2007. Responses of hyporheic invertebrate assemblages to large-scale variation in flow permanence and surfacesubsurface exchange. Freshwater Biology 52:1452-1462.

Dent, C. L., N. B. GrimM, AND S. G. Fisher. 2001. Multiscale effects of surface-subsurface exchange processes between rivers and groundwater. Iournal of the North American Benthological Society 20:162-181. 
Doering, M., U. Uehlinger, A. Rotach, AND D. R. Schlaepfer. 2007. Ecosystem expansion and contraction dynamics along a large alpine alluvial corridor (Tagliamento River, Northeast Italy). Earth Surface Processes and Landforms 32:1693-1704.

Dunkerley, D., AND K. BRown. 1999. Flow behaviour, suspended sediment transport and transmission losses in a small (sub-bank-full) flow event in an Australian desert stream. Hydrological Processes 13:1577-1588.

EBINA, J., T. TsutsuI, AND T. SHIRAI. 1983. Simultaneous determination of total nitrogen and total phosphorus in water using peroxodisulfate oxidation. Water Research 17:1721-1726.

Fernald, A. G., P. J. Wigington, and H. L. Dixon. 2001. Transient storage and hyporheic flow along the Willamette River, Oregon: field measurements and model estimates. Water Resources Research 37:1681-1694.

Fontana, A., P. MozzI, AND A. Bondesan. 2008. Alluvial megafans in the Venetian-Friulian plain (North-Eastern Italy): evidence of sedimentary and erosive phases during late Pleistocene and Holocene. Quaternary International 189:71-90.

Franken, R. J. M., R. G. Storey, and D. D. Williams. 2001. Biological, chemical and physical characteristics of downwelling and upwelling zones in the hyporheic zone of a north-temperate stream. Hydrobiologia 444: 183-195.

Frissell, C. A., W. J. Liss, C. E. Warren, And M. D. Hurley. 1986. A hierarchical framework for stream habitat classification: viewing streams in a watershed context. Environmental Management 10:199-214.

Gasith, A., AND V. H. Resh. 1999. Streams in Mediterranean climate regions: abiotic influences and biotic responses to predictable seasonal events. Annual Review of Ecology and Systematics 30:51-81.

Healey, F. P., And L. L. Hendzel. 1975. Effect of phosphorus deficiency on two algae growing in chemostats. Journal of Phycology 11:303-309.

HendRICKS, S. P. 1993. Microbial ecology of the hyporheic zone: a perspective integrating hydrology and biology. Journal of the North American Benthological Society 12: 70-78.

Hill, W. R., AND H. L. Boston. 1991. Community development alters photosynthesis-irradiance relations in stream periphyton. Limnology and Oceanography 36:10-23.

JONES, J. B. 1995. Factors controlling hyporheic respiration in a desert stream. Freshwater Biology 34:91-99.

Jones, J. B., S. G. Fisher, AND N. B. GRIMM. 1995. Vertical hydrologic exchange and ecosystem metabolism in a Sonoran desert stream. Ecology 76:942-952.

Kasahara, T., and S. M. Wondzell. 2003. Geomorphic controls on hyporheic exchange flow in mountain streams. Water Resources Research 39:1005-1019.

Langhans, S. D., S. D. Tiegs, U. Uehlinger, And K. Tockner. 2006. Environmental heterogeneity controls organicmatter dynamics in river floodplain ecosystems. Polish Journal of Ecology 54:675-680.

LARNED, S. T., T. DAtry, AND C. T. Robinson. 2007. Invertebrate and microbial responses to inundation in an ephemeral river reach in New Zealand: effects of preceding dry periods. Aquatic Sciences 69:554-567.

Lowe, W. L., G. E. Likens, And M. E. Power. 2006. Linking scales in stream ecology. BioScience 56:591-597.

Malard, F., K. Tockner, M. J. Dole-Oliver, and J. V. Ward. 2002. A landscape perspective of surface-subsurface hydrological exchanges in river corridors. Freshwater Biology 47:621-640.

Malard, F., K. Tockner, And J. V. WARD. 1999. Shifting dominance of subcatchment water sources and flow paths in a glacial floodplain, Val Roseg, Switzerland. Arctic, Antarctic and Alpine Research 31:135-150.

Malard, F., K. Tockner, and J. V. Ward. 2000. Physicochemical heterogeneity in a glacial riverscape. Landscape Ecology 15:679-695.

Malard, F., U. Uehlinger, R. Zah, And K. Tockner. 2006. Flood-pulse and riverscape dynamics in a braided glacial river. Ecology 87:704-716.

Marxsen, J., A. Zoppini, AND S. WilczeK. 2010. Microbial communities in streambed sediments recovering from desiccation. FEMS Microbiology Ecology 71:374-386.

Meyns, S., R. Illi, and B. RiBI. 1994. Comparison of chlorophyll $a$ analysis by HPLC and spectrophotometry: where do the differences come from? Archiv für Hydrobiologie 132:129-139.

Naegeli, M. W., U. Hartmann, E. I. Meyer, and U. Uehlinger. 1995. POM dynamics and community respiration in the sediments of a floodprone prealpine river (Necker, Switzerland). Archiv für Hydrobiologie 133:339-347.

Naegeli, M. W., AND U. Uehlinger. 1997. Contribution of the hyporheic zone to ecosystem metabolism in a prealpine gravel-bed river. Journal of the North American Benthological Society 16:794-804.

Parsons, M., And M. C. Thoms. 2007. Hierarchical patterns of physical-biological associations in river ecosystems. Geomorphology 89:127-146.

Poole, G. C., S. J. O'Daniel, K. L. Jones, W. W. Woessner, E. S. Bernhardt, A. M. Helton, J. A. Stanford, B. R. Boer, and T. J. BEechie. 2008. Hydrologic spiralling: the role of multiple interactive flow paths in stream ecosystems. River Research and Applications 24:1018-1031.

Poole, G. C., J. A. Stanford, C. A. Frissell, and S. W. RunNING. 2002. Three-dimensional mapping of geomorphic controls on flood-plain hydrology and connectivity from aerial photos. Geomorphology 48:329-347.

Poole, G. C., J. A. Stanford, S. W. Running, and C. A. FRISSELL. 2006. Multiscale geomorphic drivers of groundwater flow paths: subsurface hydrologic dynamics and hyporheic habitat diversity. Journal of the North American Benthological Society 25:288-303.

Poole, G. C., J. A. Stanford, S. W. Running, C. A. Frissell, W. W. Woessner, AND B. K. Ellis. 2004. A patch hierarchy approach to modeling surface and subsurface hydrology in complex flood-plain environments. Earth Surface Processes and Landforms 29:1259-1274.

Pusch, M., AND J. Schwoerbel. 1994. Community respiration in hyporheic sediments of a mountain stream (Steina, Black Forest). Archiv für Hydrobiologie 130:35-52. 
RHEE, G. Y. 1978. Effects of N:P atomic ratios and nitrate limitation on algal growth, cell composition, and nitrate uptake. Limnology and Oceanography 23:10-25.

SOKAL, R. R., AND F. J. RoHLF. 1995. Biometry: the principles and practice of statistics in biological research. $3^{\text {rd }}$ edition. Freeman, New York.

Stanford, J. A., M. S. Lorang, and F. R. Hauer. 2005. The shifting habitat mosaic of river ecosystems. Verhandlungen der Internationalen Vereinigung für theoretische und angewandte Limnologie 29:123-136.

Stanley, E. H., S. G. Fisher, and J. B. Jones. 2004. Effects of water loss on primary production: a landscape-scale model. Aquatic Sciences 66:130-138.

Thorp, J. H., M. C. Thoms, and M. D. Delong. 2006. The riverine ecosystem synthesis: biocomplexity in river networks across space and time. River Research and Applications 22:123-147.

Tockner, K., F. Malard, P. Burgherr, C. T. Robinson, U. Uehlinger, R. ZAH, AND J. V. WARd. 1997. Physicochemical characterization of channel types in a glacial floodplain ecosystem (Val Roseg, Switzerland). Archiv für Hydrobiologie 140:433-463.

Tockner, K., J. V. Ward, D. B. Arscott, P. J. Edwards, J. Kollmann, A. M. Gurnell, G. E. Petts, and B. Maiolini. 2003. The Tagliamento River: a model ecosystem of European importance. Aquatic Sciences 65:239-253.

UEHLINGER, U. 1981. Ecology of the planktonic blue-green alga Aphanizomenon flos-aquae in Alpine lakes. Schweizerische Zeitschrift für Hydrologie - Swiss Journal of Hydrology 43:69-88.
UEHLINGER, U. 1991. Spatial and temporal variability of the periphyton biomass in a prealpine river (Necker, Switzerland). Archiv für Hydrobiologie 123:219-237.

Uehlinger, U., M. W. Naegeli, and S. G. Fisher. 2002. A heterotrophic desert stream? The role of sediment stability. Western North American Naturalist 62:466-473.

Uehlinger, U., AND R. ZAH. 2003. Organic matter dynamics. Pages 199-215 in J. V. Ward and U. Uehlinger (editors). Ecology of a glacial floodplain. Kluwer Academic Publishers, Dordrecht, The Netherlands.

Valett, H. M., S. G. Fisher, N. B. Grimm, And P. CAmill. 1994. Vertical hydrologic exchange and ecological stability of a desert stream ecosystem. Ecology 75:548-560.

Van Gestel, M., R. Merckx, and K. Vlassak. 1993. Microbial biomass and activity in soils with fluctuating water contents. Geoderma 56:617-626.

White, D. S. 1993. Perspectives on defining and delineating hyporheic zones. Journal of the North American Benthological Society 12:61-69.

Wyatt, K. H., F. R. Hauer, And G. F. Pessoney. 2008. Benthic algal response to hyporheic-surface water exchange in an alluvial river. Hydrobiologia 607:151-161.

ZAH, R. 2001. Patterns, pathways, and trophic transfer of organic matter in a glacial stream ecosystem in the Alps. PhD Thesis, ETH, Zurich, Switzerland.
Received: 1 February 2012 Accepted: 26 September 2012 